\title{
Nutrient content of Bambara groundnut (Vigna subterranea) and the effects of its inclusion on the performance of growing broiler chickens and on egg production and quality
}

\author{
F. Fru Nji ${ }^{1}$, E. Niess and E. Pfeffer \\ Department of Animal Nutrition, University of Bonn \\ Endenicher Allee 15, D-53115, Bonn, Germany
}

(Received 19 September 2003; revised version 1 April 2004; accepted 16 June 2004)

\begin{abstract}
Bambara groundnut (Vigna subterranea) was analysed for its nutrients content, and subsequently included into standard wheat-soyabean meal diets at the expense of wheat and soyabean meal. All diets had similar crude protein and total lipids contents and met the amino acids, minerals and vitamins requirements according to NRC (1994). In the $1^{\text {st }}$ experiment broiler chickens, kept in individual metabolic cages, were allotted to either a control, or one of 4 test groups, ten birds per treatment. The experiment lasted from $12^{\text {th }}$ to $27^{\text {th }}$ day of life. Growth performance, nutrient balance and energy metabolizability were determined.

In a $2^{\text {nd }}$ experiment 35 -weeks old Lohmann laying hens were allotted into 4 deep litter pens of 5 layers each. Birds received either a control diet or a test diet containing $451 \mathrm{~g}$ Bambara $/ \mathrm{kg}$ feed. During 10 weeks, egg production and quality were determined.

Bambara groundnut inclusion in growing broiler diets had no effect on the feed intake; it contains 12.6 MJ AME $/ \mathrm{kg} \mathrm{DM}$. There was a progressive decrease in weight gain of the chickens, significant at and above $571 \mathrm{~g} / \mathrm{kg}$ inclusion. Inclusion of $451 \mathrm{~g}$ Bambara/ $\mathrm{kg}$ layers feed had no significant effect on egg production and the quality of eggs fell within an acceptable range.
\end{abstract}

KEY WORDS: Bambara groundnut, Vigna subterranea, nutrients, broiler, egg quality, metabolizable energy

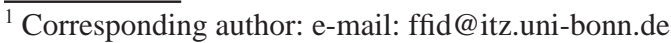




\section{INTRODUCTION}

The world animal feed industry relies on conventional feedstuffs. Most of these are also food for humans. In developing countries where there is an immense food shortage, using these conventional foodstuffs for animals is most unlikely and transcends into low meat production. This brings into focus the necessity of looking at other sources of feedstuffs, which are not competed for by man and animals. Bambara groundnut is one of such unconventional grain. It is a low growing tropical legume, forming its seeds in pods beneath the earth and is closely related to the peanut plant. It is found in most tropical and subtropical regions of the world, can withstand hash climatic and soil conditions (Hepper, 1970; Dakora, 1992) and grows within 4 months (Doku and Karikari, 1970). The world production in 1982 was estimated at 330, 000 tons (Courdet, 1982) and in 2003 at 58,000 tons (FAO, 2004) although it has a potential of 4 tons/ha (Tanimu and Yayock, 1990). The low production is probably due to the low demand, which itself could be associated to the lack of information to its potential use. The nutrients content of Bambara are reported by a few authors and, just like most under-researched plant seeds, vary enormously. It has been reported to contain in $\mathrm{g} / \mathrm{kg}$ air-dried: crude protein, 144 to 225 , N-free extractives, 529 to 693, total lipids, 60 to 85, and ash 25 to 50 (Busson and Bergeret, 1958; Oliviera, 1976; Nwokolo, 1987; Onimawo et al., 1998). Bonamme (1909) also reported a starch content of $518 \mathrm{~g} / \mathrm{kg}$. Being a legume antinutrional factors (ANFs) have been reported to be present in Bambara groundnut, which vary to an extend depending on cultivar. Tannins content has been reported to vary from $0.05 \%$ in the cream cultivar to $0.67 \%$ in the black (Amarteifio and Moichubedi, 1997). From 2 varieties of Bambara Apata and Ologhobo (1997) reported a trypsin content of 9.4 and $12.2 \mathrm{TIU} / \mathrm{mg}$ protein, oxalic acids of 2.1 and 2.3, anti-haemagglutinating activities of 5-7 HU/mg protein and a phytic acid of up to $397 \mathrm{mg} / 100 \mathrm{~g} \mathrm{DM}$.

The evaluation of Bambara as animal feed is limited. On broilers, Oluyemi (1975) reported an ME content of $8.2 \mathrm{MJ} / \mathrm{kg}$, while Nwokolo (1987) 12.5 MJ ME/ $\mathrm{kg}$ and a true protein digestibility of $77 \%$. Ologhobo (1992) tested 12.5 and $25 \%$ levels of inclusion of Bambara groundnut in growing broiler rations and concluded that at the $25 \%$ level the performance was significantly reduced. Fru Nji et al. (2003) reported a feed/gain ratio of about 2.1 and an apparent protein retention of about $50 \%$ for Bambara on growing broiler chickens. There is, however, a big gap in the knowledge of the nutrient content of Bambara groundnut, the digestibility of its nutrients and its effect on growing broiler chickens and performance of laying hens. More information on these would go a long way to enable its inclusion not only in poultry rations but also in other livestock rations and consequently, through demand, encourage the optimization of its production. 


\section{MATERIAL AND METHODS}

\section{Bambara analysis}

Samples of Bambara originating from West Africa were analysed according to the standard methods given by Naumann and Bassler (1976). Starch and sugars were determined by use of optical polarimetry and Luff-Schoorl methods, respectively. The gross energy (GE) was estimated using an adiabatic bomb calorimeter. A spectrophotometric method from a combination of the Lepper and von-Lorenz methods was used for $\mathrm{P}$ determination. $\mathrm{Ca}, \mathrm{Mg}, \mathrm{Na}$ and $\mathrm{K}$ were estimated by atomic absorption spectrophotometry. The amino acid profile was determined in Degussa Hüls AG, Hanau according to VDLUFA (1997), the sulphone amino acids were first oxidised to methionine-sulphone and cysteic acids before hydrolysis.

\section{Feeding trials}

Broilers. Seventy one-day-old Lohmann broiler chickens kept in battery cages were fed for ten days on a commercial broiler starter diet, transferred to individual metabolic cages and allowed to acclimatize for 2 days. At 12 days of age, 50 birds of $245 \mathrm{~g}$ average body weight were assigned to one of 5 treatment groups with ten replications each. Chickens were fed either a control diet or one of 4 test diets containing 192, 381, 571, and $762 \mathrm{~g}$ Bambara groundnut $/ \mathrm{kg}$ feed (Table 1). Diets were formulated to be similar in crude protein, total lipids and gross energy. Each diet was fine-milled, a proximate analysis was carried out and energy content measured using the methods described in the section for Bambara analysis. Feed and water were provided ad libitum. The experiment lasted from the $12^{\text {th }}$ to the $27^{\text {th }}$ day of life, every 5 days performance parameters were measured. Excreta was collected from trays placed at the bottom of the cages, cleared of feathers freeze-dried, fine-milled and analysed for nutrient and energy content. A slight modification of the $\mathrm{TiO}_{2}$ marker method as described by Short et al. (1996) was used for determining energy metabolizability and the apparent nutrient retention.

Laying hens. Twenty 35-week old Lohmann laying hens, weighing an average of $1800 \mathrm{~g}$, with a hen-day egg production of about $80 \%$ and egg weight of $63 \mathrm{~g}$, were kept in 4 deep litter box pens, 5 per pen. Hens in 2 pens were fed a control diet (II-0) without Bambara while the other pens were fed a test diet (II-45) containing $451 \mathrm{~g}$ Bambara groundnuts per $\mathrm{kg}$ feed (Table 1). Feed and water were provided ad libitum. $16 \mathrm{~lx}$ of light was provided for $16 \mathrm{~h}$ a day. Eggs were collected daily and weighed. Feed intake and liveweight of the birds were recorded every week. Three egg-quality-examinations were performed on eggs collected from all 
TABLE 1

Composition of experimental diets, $\mathrm{g} / \mathrm{kg}$

\begin{tabular}{|c|c|c|c|c|c|c|c|}
\hline \multirow{2}{*}{ Item } & \multicolumn{5}{|c|}{ Broilers } & \multicolumn{2}{|c|}{ Layers } \\
\hline & $\mathrm{I}-0$ & $\mathrm{I}-19$ & $\mathrm{I}-38$ & $\mathrm{I}-57$ & I-76 & II-0 & II-45 \\
\hline \multicolumn{8}{|l|}{ Diets } \\
\hline Bambara groundnut meal & - & 192 & 381 & 571 & 762 & - & 451 \\
\hline soyabean meal & 279 & 223 & 167 & 112 & 56 & 261 & 131 \\
\hline wheat & 626 & 500 & 376 & 250 & 125 & 590 & 296 \\
\hline soyabean oil & 50 & 40 & 30 & 20 & 10 & 47 & 25 \\
\hline Premix $^{1}$ & 4 & 4 & 4 & 4 & 4 & 25 & 25 \\
\hline lysine-HCL & 1 & - & - & - & - & & \\
\hline mono-calcium phosphate & 22 & 23 & 24 & 25 & 25 & & \\
\hline calcium carbonate & 10 & 10 & 10 & 10 & 10 & 77 & 72 \\
\hline constant components ${ }^{2}$ & 8 & 8 & 8 & 8 & 8 & & \\
\hline \multicolumn{8}{|l|}{ Calculated, $\mathrm{g} / \mathrm{kg}$} \\
\hline crude protein & 194 & 194 & 193 & 192 & 192 & 175 & 175 \\
\hline total lipid & 74 & 74 & 75 & 75 & 76 & 70 & 68 \\
\hline $\mathrm{Ca}$ & 10.2 & 10.2 & 10.2 & 10.2 & 10.2 & 36.0 & 36.0 \\
\hline $\mathrm{P}$ & 9.8 & 9.8 & 9.8 & 9.7 & 9.7 & 6.3 & 3.5 \\
\hline $\mathrm{Na}$ & 1.4 & 1.4 & 1.4 & 1.4 & 1.5 & 1.7 & 1.7 \\
\hline Met + Cys & 8.1 & 8.0 & 7.9 & 7.8 & 7.7 & 5.8 & 5.5 \\
\hline Lys & 10.1 & 10.7 & 11.3 & 11.9 & 12.3 & 8.6 & 10.5 \\
\hline Val & 10.6 & 10.5 & 10.4 & 10.4 & 10.3 & 8.0 & 8.0 \\
\hline $\mathrm{ME}, \mathrm{MJ} / \mathrm{kg}^{3}$ & 13.0 & 12.9 & 12.7 & 12.6 & 12.5 & 11.8 & 11.6 \\
\hline
\end{tabular}

${ }^{1}$ commercial vitamin and mineral premixes for broilers and for layers

${ }^{2}$ supplied per kg diet, g: DL-methionine (98\%) 2; valine 2; $\mathrm{NaCl} 3$; titanium dioxide (marker)

${ }^{3}$ calculated assuming 12.5 MJ ME $/ \mathrm{kg}$ for Bambara according to Nwokolo (1987)

treatment groups, in the $4^{\text {th }}, 7^{\text {th }}$ and $10^{\text {th }}$ experimental weeks. The egg, shell and yolk were weighed to the nearest $0.1 \mathrm{~g}$. Shell strength was measured in $\mathrm{kg}$ using a pressure gauge. A Vernier calliper was used to measure the length and breadth of the albumen, and the breadth of the yolk. A micrometer screw height gauge was used to measure yolk height, and albumen height, which was measured midway between the yolk and the edge of the inner thick albumen. Yolk index (YI) and albumen index (AI) were calculated as follows:

$$
\begin{gathered}
\mathrm{YI}=(\text { yolk height } / \text { yolk breadth }) \times 100 \\
\mathrm{AI}=[\text { albumen height } /((\text { albumen breadth }+ \text { albumen length }) / 2)] \times 1000
\end{gathered}
$$

The yolk colour was measured using la Roche colour fan. The experiment lasted 10 weeks. 


\section{Statistical analysis}

All data were analysed by one-way ANOVA (experiment I) or a t-test (experiment II) in the Graph Pad Prism Version 3.00 for Windows, statistical package, $\mathrm{P} \leq 0.05$ was considered to be significant and a Tukey test was performed to compare means. The relationships between levels of Bambara groundnut in diet and performance parameters were also established by statistical regressions using Excel of Microsoft Office 2000 package.

\section{RESULTS}

Nutrient content of Bambara groundnut are presented in Table 2.

TABLE 2

Composition of Bambara groundnut

\begin{tabular}{|c|c|c|c|c|}
\hline \multirow{2}{*}{\multicolumn{2}{|c|}{$\begin{array}{l}\text { Nutrients } \\
\text { g/kg DM }\end{array}$}} & \multicolumn{3}{|c|}{ Amino acids } \\
\hline & & amino acid & $\mathrm{g} / \mathrm{kg} \mathrm{DM}$ & $\mathrm{G} / 16 \mathrm{~g} \mathrm{~N}$ \\
\hline $\mathrm{DM}, \mathrm{g} / \mathrm{kg}$ & 910 & Methionine & 3.2 & 1.45 \\
\hline Crude protein & 221 & Cysteine & 3.1 & 1.40 \\
\hline Ether extract & 80 & Methionine + cysteine & 6.3 & 2.85 \\
\hline Crude fibre & 52 & Lysine & 15.5 & 6.97 \\
\hline Ash & 30 & Threonine & 7.7 & 3.45 \\
\hline $\mathrm{N}$-free extractives & 620 & Arginine & 15.4 & 6.94 \\
\hline Starch & 296 & Isoleucine & 8.5 & 3.83 \\
\hline Sugar & 39 & Leucine & 17.4 & 7.83 \\
\hline $\mathrm{P}$ & 0.30 & Valine & 9.9 & 4.45 \\
\hline $\mathrm{Ca}$ & 0.06 & Histidine & 7.1 & 3.19 \\
\hline $\mathrm{Mg}$ & 0.18 & Phenylalanine & 3.6 & 6.12 \\
\hline $\mathrm{Na}$ & 0.02 & Glycine & 8.5 & 3.81 \\
\hline \multirow[t]{2}{*}{ K } & 1.85 & Serine & 1.8 & 5.32 \\
\hline & & Proline & 9.6 & 4.30 \\
\hline \multirow[t]{3}{*}{ Gross energy, MJ / kg DM } & 19.7 & Alanine & 9.3 & 4.19 \\
\hline & & Aspartic acid & 26.2 & 11.79 \\
\hline & & Glutamic acid & 39.0 & 17.53 \\
\hline
\end{tabular}

\section{Broiler trial}

The level of Bambara groundnut in the diets had no significant influence on the feed intake (Table 3). Birds receiving diet I-57 and I-76 had a significantly lower body weight gain (BWG) when compared to the control while there were no significant differences in BWG between any diets containing Bambara groundnut (I-19 - I-76). There was a steady decreasing trend with increasing Bambara ground- 
nut level in diets. Also feed conversion ratio, decreased as the Bambara groundnut inclusion level in the diet increased, this value, however, remained comparable to the control up to the $571 \mathrm{~g} / \mathrm{kg}$ inclusion level.

TABLE 3

Performance of broiler chickens, 12-27 day of age

\begin{tabular}{lcccccc}
\hline Diets $^{1}$ & I-0 & I-19 & I-38 & I-57 & I-76 & SEM \\
\hline Feed intake, g & 1336 & 1325 & 1363 & 1228 & 1259 & 22 \\
Weight gain, g & $834^{a}$ & $781^{a b}$ & $767^{a b}$ & $701^{b}$ & $684^{b}$ & 14 \\
Feed/gain ratio & $1.61^{a}$ & $1.70^{a b}$ & $1.77^{a b}$ & $1.76^{a b}$ & $1.85^{b}$ & 0.02
\end{tabular}

Apparent retention of nutrients and energy metabolizability, \%

$\begin{array}{lllllll}\text { dry matter } & 69.9^{a} & 66.8^{a b} & 64.3^{a b} & 63.0^{b} & 60.3^{b} & 0.9 \\ \text { crude protein } & 57.5^{a} & 54.5^{a b} & 51.4^{a b} & 51.0^{a b} & 49.2^{b} & 0.9 \\ \text { organic matter } & 69.8^{a} & 68.1^{a} & 66.2^{a b} & 64.5^{a b} & 62.1^{b} & 0.8 \\ \text { ether extract } & 88.1^{a} & 86.3^{a b} & 85.4^{a b} & 84.4^{b} & 82.9^{b} & 0.5 \\ \text { energy } & 74.7^{a} & 71.7^{a b} & 69.8^{a b} & 69.0^{\mathrm{b}} & 66.8^{\mathrm{b}} & 0.8\end{array}$

Protein (g CP intake/kg BWG) and energy (MJ ME intake/kg BWG) utilization

\begin{tabular}{lcccccl} 
protein & 0.34 & 0.36 & 0.37 & 0.36 & 0.37 & 0.004 \\
energy & 21.9 & 21.9 & 22.6 & 22.0 & 22.2 & 0.22 \\
\hline
\end{tabular}

figures with different superscripts are significantly different at $\mathrm{P} \leq 0.05$

BWG: body weight gain

${ }^{1}$ explanation - see Table 1

The apparent retention of DM decreased with increasing dietary level of Bambara groundnut, being significant $(\mathrm{P} \leq 0.05)$ as the inclusion level rose to and exceeded $571 \mathrm{~g} / \mathrm{kg}$ (I-57). Increasing the level of Bambara groundnut in a diet reduced the apparent retention of organic matter, crude protein and ether extract. At $762 \mathrm{~g}$ Bambara groundnut inclusion, the apparent retention of both organic matter and crude protein became significantly lower than in the control. The metabolizability of energy showed a steady decreasing trend with increasing levels of Bambara groundnut in the diets, and became significantly lower than I-0, when the dietary Bambara groundnut level was increased to $571 \mathrm{~g} / \mathrm{kg}$ and beyond.

There were no significant differences in the efficiencies of energy and protein utilization. The efficiency of energy utilization, however, decreased with increasing Bambara level in the diets (Table 3).

\section{Laying hen trial}

There was no significant difference in feed intake between the control and test group, although II-45 hens seemed to have consumed slightly less than the control (Table 4). The hen-day egg production (laying rate) of the control was better than 
that of the test group, but the difference was not statistically significant. There were no significant differences between the control and the test diet in the CP and ME intakes although they were lower in the test group. The efficiency of CP utilization ( $\mathrm{g} \mathrm{CP} / 100 \mathrm{~g}$ egg weight) was better in the control diet, just as much as the efficiency of ME utilization (MJ ME/kg egg).

TABLE 4

Performance of laying hens, 35-45 week of life

\begin{tabular}{|c|c|c|c|c|}
\hline Diets $^{1}$ & II-0 & II-45 & & \\
\hline Feed intake /hen and day, g & 101 & 97 & & \\
\hline Hen-day egg production, $\%$ & 78.3 & 69.6 & & \\
\hline \multicolumn{5}{|c|}{ Efficiency of total CP and ME utilization in egg production } \\
\hline CP intake, $\mathrm{g} / \mathrm{hen}$ and day & 17.77 & 17.00 & & \\
\hline ME intake, $\mathrm{MJ} /$ hen and day & 1.20 & 1.12 & & \\
\hline g CP/100 g egg weight & 36.0 & 40.1 & & \\
\hline $\mathrm{MJ}, \mathrm{ME} / \mathrm{kg}$ egg & 24.3 & 26.4 & & \\
\hline Egg quality & & & SEM & P-level \\
\hline $\mathrm{n}$ & 71 & 63 & & \\
\hline egg weight, g/egg & 63.5 & 61.0 & 0.63 & $* *$ \\
\hline shell strength, kg & 4.7 & 5.0 & 0.10 & $*$ \\
\hline shell, $\%$ & 11.9 & 12.0 & 0.13 & ns \\
\hline yolk colour level & 3.7 & 3.6 & 0.23 & ns \\
\hline yolk, \% & 27.9 & 26.6 & 0.32 & $*$ \\
\hline yolk index & 46.9 & 46.6 & 0.41 & ns \\
\hline albumen, \% & 60.1 & 61.4 & 0.35 & $*$ \\
\hline albumen index & 79.4 & 82.6 & 2.55 & ns \\
\hline$\%$ of eggs with blood spots & 21 & 14 & & \\
\hline$\%$ of cracked eggs & 7 & 4 & & \\
\hline
\end{tabular}

The results (Table 4) showed that there was a significant drop in the average egg weights in the Bambara groundnut containing diet as compared to the control.

Eggs from hens fed Bambara groundnut had lower mass and stronger shells than the control group. Egg yolk colour did not differ. The yolk fraction of the control group was significantly higher than that of the test group, while the reverse was found for the albumen fraction. The yolk and albumen indices did not differ significantly. 


\section{DISCUSSION}

The CP and crude fibre content of Bambara groundnut determined in this study were about 22 and $5.2 \%$, respectively, similar to those reported from other studies (Nwokolo, 1987; Ologhobo, 1992). However, the content of ether extract (7.5\%) in this study was much higher than the $2.85 \%$ reported by Nwokolo (1987). The similarity in the nutrients content from this study to those of Nwokolo (1987) and Ologhobo (1992) could be due to the fact that the nuts all originating from the same geographical region (West Africa). The differences in the nutrient content found in this study to those reported by the authors in the introduction could be to a large extent due to the geographical origin and also the cultivar used.

The CP content of Bambara groundnut is low, when compared to soyabean meal (Petersen, 2001). An estimation of the apparent ME, using the GfE (1999) formula: $\mathrm{AME}=15.51(\mathrm{CP})+34.31(\mathrm{EE})+16.69(\mathrm{starch})+13.01$ (sugar), gives an $\mathrm{ME}$ of about $12 \mathrm{MJ} / \mathrm{kg}$.

The $22 \% \mathrm{CP}$ content of Bambara is not high enough for it to be used as a primary protein source (supplement) in concentrate formulations. However, the CP is almost double that of most commonly used cereals although the starch and sugar are lower. Energy estimated from total lipids, starch and sugar, though greater than in other legumes, is much lower than in cereals, making Bambara a poor energy source. The concentration of amino acids in Bambara (Table 2) covers almost all amino acid requirements (NRC, 1994; GfE, 1999) of growing broiler chickens. Aspartic acid and glutamic acid are dominant as in other legumes. The concentration of amino acids in Bambara groundnut covered amino acid requirements of laying hens (NRC, 1994). These nutrients content allowed for trying Bambara groundnut at very high inclusion levels in broiler diets without modification of the CP, ether extract and GE levels.

Bambara groundnut had no significant effect on the palatability of the diets or did not contain any anti-nutritional factors that could influence feed intake. In a study Ologhobo (1992) reported that feed intake of broilers fed $12.5 \%$ Bambara groundnut was not significantly different while, at $25 \%$ level, it was significantly lower than the control group. Similar trends have also been reported in other species of Vigna. Gupta et al. (1991) included up to 40\% Vigna umbellata in broiler rations with no significant reduction in feed intake. Lon Wo et al. (1998) reported a 35\% inclusion of Vigna unguiculata in broiler diets and from 7 - 49 days old, had no significant effects on the feed intake. The feed to gain ratio in this study remained comparable to the control up to $60 \%$ Bambara inclusion. Lon Wo et al. (1998) also reported no significant difference in the FCR when they fed a 35\% Vigna unguiculata containing diet to growing broiler chickens.

The apparent retention of nutrients reflected the growth performance of the animals. The apparent retention of organic matter (OM) and CP were comparable 
to the control at up to $57 \%$ Bambara groundnut inclusion, while ether extract was only up to $38 \%$. Since wheat contains more starch and sugar than Bambara groundnut, the starch and sugar content of the diets decreased with increasing Bambara groundnut, which may account for the low apparent retention of OM. The decline in the apparent retention of CP could be partly due to the presence of anti-nutritional factors such as protease inhibitors, tannins and other polyphenols that may intervene with the digestibility of proteins in the Bambara groundnut (Liener and Kakade, 1980; Odumodu, 1992; Essien and Akaninwor, 2000).

All diets were balanced for total lipids (ether extract) content by supplementing those containing more wheat and soyabean meal with vegetable oil, which is almost $100 \%$ digestible. It is possible that the lipids in Bambara groundnut are less digestible than soya lipids since the apparent retention of ether extract decreased with increasing dietary Bambara groundnut level. The metabolizability of energy decreased linearly $\left(\mathrm{R}^{2}=0.97 ; \mathrm{y}=74.1-0.0974 \mathrm{x}\right)$ with increasing Bambara groundnut in the diets. The metabolizability of energy in Bambara calculated by regression was 64.4\%, giving 12.6 MJ AME/kg DM Bambara. The lower digestibility of starch in legumes for poultry (McNab et al., 1999) could reduce the metabolizability of energy. The calculated apparent retention of Bambara $\mathrm{CP}\left(\mathrm{R}^{2}=0.94 ; \mathrm{y}=56.7-0.1058 \mathrm{x}\right)$ was $46 \%$.

No significant differences were found in the $\mathrm{CP}$ utilization, although one would have expected the utilization to be better at low levels of Bambara, due to the decrease in weight gain. The ME intake and weight gain decreased with increasing Bambara in the diet, as a result the efficiency of energy utilization remained comparable at all levels.

In the laying hen trial, the egg production of the test group was about $90 \%$ of the control. There were no major differences in the efficiency of protein utilization for egg production. The summarized results of the egg quality evaluation after 10 weeks indicate that there were no significant differences in yolk colour, yolk index and the albumen index. The presence of the Bambara groundnut in diets significantly reduced the weight of eggs. In general the test birds produced eggs that were stronger, smaller and had more albumen than the control, while the control produced eggs that had larger yolk than the test group. Since there were no differences in the yolk colour, it means that Bambara groundnut has a concentration of carotenoids that is as low as that of wheat, which has been reported to produce egg yolks with a la Roche fan colour level of 4 (Seemann, 1999). Despite some of the differences noticed in certain egg quality parameters, hens in II- 0 and II-45 laid eggs with qualities that fell within an acceptable range (Kräusslich and Brem, 1997).

\section{CONCLUSIONS}

In this study, it was found that in growing broilers Bambara groundnut has a metabolizable energy of $12.6 \mathrm{MJ} / \mathrm{kg} \mathrm{DM}$ and crude protein retention of about 
46\%. Between 40 and 60\% Bambara groundnut could be included into grower diets for broilers. After 10 weeks of feeding 50\% Bambara groundnut, it had no significant effects as compared to a standard European layer diet, on the laying performance of 35 weeks old laying hens, despite the fact that there was a negative performance tendency. The hens produced eggs with acceptable qualities.

\section{REFERENCES}

Amarteifio J.O., Moichubedi E., 1997. Condensed tannin content of four landraces of Bambara groundnut (Vigna subterranea (L). Verdc). Tropenlandwirt. 139-142

Apata D.F., Ologhobo A.D., 1997. Trypsin inhibitor and other anti-nutritional factors in tropical legume seeds. Trop. Sci. 37, 52-59

Bonamme P., 1909. Pistache malgache (Bambara groundnut). Bull. Econ. Colonie de Madagascar et Dépendences 9 (2), 446-450

Busson F., Bergeret B., 1958. Contribution à l'études chimiques des graines de Voandzeia subterranea (Thouars) papilionacées. Acta Trop. 15 (3), 246-250

Courdet M.J., 1982. Niébé et voandzu; une perspective pour le dévelopement du commerce régional en Afrique de l'ouest. Int. Trade Centre UNCTAD/GATT, Genève

Dakora F.D., Atkins C.A., Pate J.S., 1992. Effect of $\mathrm{NO}_{3}$ on $\mathrm{N}_{2}$ fixation and nitrogenous solutes of xylem in two nodulated West African geocarpic legumes, Karsting's bean (Macrotyloma geocarpum L.) and Bambara groundnut (Vigna subterranea L.). Plant Soil 142, 255-262

Doku E.V., Karikari S.K., 1970. Fruit development in bambarra groundnut (Voandzeia subterranea) Ann. Bot. 34, 951-956

Essien E.B., Akaninwor J.O., 2000. Effect of processing on the nutritional quality of African yam bean (Sphenostylis stenocarpa) and Bambara groundnut (Voandzeia subterranea). Global J. Pure Appl. Sci. 6, 181-186

FAO, 2004. Online Production Statistics http://faostat.fao.org/faostat/ (query date; $20^{\text {th }}$ March 2004)

Fru Nji F., Niess E., Pfeffer E., 2003. Effects of raw and heat-treated Bambara groundnut (Vigna subterranea) on the performance and body composition of growing broiler chicks. Arch. Anim. Nutr. 57, 443-453

GfE (Gesselschaft für Ernährungsphysiology), 1999. Empfehlung zur Energie- und Nähstoffversorgung der Legehennen und Masthühner (Broiler). DLG-Verlag, Frankfurt am Main, pp. 16

Gupta J.J., Yadav B.P.S., Gupta H.K., 1991. Rice bean (Vigna umbellata) as poultry feed. Indian J. Anim. Sci. 9, 59-62

Kräusslich H., Brem G., 1997. Tierzucht und Allgemeine Landwirtschaftslehre für Tiermediziner. Ferdinand Enke Verlag, Stuttgart (Germany)

Liener I.E., Kakade M.L., 1980. Protease Inhibitors. Toxic Constituents of Plant Foodstuff. I.E. Liener. New York, Academic Press, pp. 7-77

Lon-Wo E., Cardenas M., Diaz M. F., 1998. Vigna, an alternative protein source for poultry in the tropics. Preliminary results. Cuban J. Agr. Sci. 32, 279-284

McNab J.M., 1991. Toxic factors in crop plants. In: Proceedings of the $2^{\text {nd }}$ Spring Conference. Edinburgh, Scottish Agricultural College Edinburgh, Edinburgh (UK)

Naumann C., Bassler R., 1976. LUFA. Verband Deutscher Landwirtschaftlicher Untersuchungs- und Forschungsnstalten-LUFA (Association of German Experimentation and Research Institutes) 
NRC, 1994. Nutrient Requirements of Poultry. National Academic Press, Washington, DC

Nwokolo E., 1987. Nutritional assessment of African Yam bean (Sphenostylis stenocarpa (Hochst ex A. Rich) Harms. and Bambara groundnut (Voandzeia subterranean, L.) J. Sci. Food Agr. 41, 123-129

Odumodu C.U., 1992. Antinutritional content of some locally available legumes and cereals in Nigeria. Trop. Geogr. Med. 44, 260-263

Oliviera J.S., 1976. Grain legumes of Mozambique. Tropical Grain Legume. Bull. 3, 13-15

Ologhobo A.D., 1992. Nutritive values of some tropical (West African) legumes for poultry. J. Appl. Anim. Res. 2, 93-104

Oluyemi J.A., Fetuga B.L., Endeley H.N., 1975. The metabolizable energy value of some feed ingredients for young chicks. Poultry Sci. 55, 611-618

Onimawo I.A., Momoh A.H., Usman A., 1998. Funtional composition and funtional properties of 4 cultivars of bambara groundnut (Voandzeia subterranea). Plant Foods Human Nutr. 53, 153-158

Petersen J., 2001. Jahrbuch für Geflügelwirtschaft. Eugen Ulmer GmbH and Co., Stuttgart (Germany)

Seemann M., 1999. Faktoren mit Einfluss auf Pigmentierung. Lohmann Information, Januar - März, 1, 9

Short F.J., Garton P., Wiseman J., Boorman K.N., 1996. Determination of titanium dioxide added as an inert marker in chicken digestibility studies. Anim. Feed Sci. Tech. 59, 215-221

Tanimu B., Yayock J.Y., 1990. Bambaranut agronomy. In: Cropping Scheme Report 1990. Legumes and Oilseeds Research Programme. Ahmadu Bello University, Institute of Agricultural Research, Zaria (Nigeria)

VDLUFA, 1997. Methodenbuch 1983. (Revision) Ergänzung 4, Landsberg/Lech, VDLUFA, pp. 392-397

\section{STRESZCZENIE}

\section{Zawartość składników pokarmowych w śrucie bambasa (Vigna subterramea) i jej wpływ na wyniki produkcyjne broilerów oraz produkcję i jakość jaj niosek}

Oznaczono skład chemiczny śruty bambasa, którą dodawano w różnych ilościach (od 192 do $762 \mathrm{~g} \mathrm{w}$ dawkach dla broilerów i $451 \mathrm{~g} / \mathrm{kg} \mathrm{w}$ dawce dla niosek) do diet standardowych, pszennosojowych, zastępując nią pszenicę i śrutę sojową poekstrakcyjną. Wszystkie diety zawierały podobną ilość białka ogólnego i tłuszczu; pokryte było zapotrzebowanie na aminokwasy, składniki mineralne i witaminy zgodnie z normami NRC (1994). W doświadczeniu trwającym od 12 do 27 dnia życia, 50 broilerów podzielono na 5 grup: kontrolną i 4 doświadczalne; ptaki trzymane były w indywidualnych klatkach metabolicznych. Oznaczono przyrosty, bilans składników pokarmowych oraz metaboliczność energii.

W doświadczeniu 2 dwadzieścia 35-tygodniowych niosek Lohman podzielonych na 4 grupy, trzymano w klatkach na głębokiej ściółce. Kury otrzymywały dawkę kontrolną lub doświadczalną, zawierającą $451 \mathrm{~g}$ bambasa/1 kg. W ciągu 10 tygodni oznaczono produkcję i jakość jaj.

Dodatek śruty z bambasa do dawek dla broilerów nie miał wpływu na pobieranie paszy. Śruta ta zawierała 12,6 MJ AME/kg s.m. Podobnie udział $451 \mathrm{~g}$ bambasa/1 kg paszy dla niosek nie miał istotnego wpływu na produkcję jaj, a ich jakość obniżyła się do dopuszczalnej granicy. 